\title{
MANUAL WORK, TECHNOLOGY, AND INDUSTRIAL HEALTH, 1918-39
}

by

\section{A. J. McIVOR*}

Workers' health in the inter-war years has been the subject of recent enquiry and was a topic that generated much contentious contemporary debate. ${ }^{1}$ The focus of discussion has been the impact of mass unemployment and consequent deprivation on standards of health, physique, and general well-being. The object here is to open up a further, so far very neglected dimension, by switching attention to the workplace, and investigating the theme of health at work in the 1920s and 1930s. ${ }^{2}$ The present generation has grown up with the knowledge that work, working conditions, and technology may seriously affect the mental and physical health and well-being of individual workers, and that health, fitness, and fatigue can considerably influence productivity levels and efficiency. Evidence of these correlations accumulated with the practical work of the Factory Inspectorate from the 1830s, the weight of experience of a relatively thin strand of welfarist, humanitarian employers (of the G. Cadbury and S. Rowntree genre), and the experimentation of "scientific management" theorizers, including the Americans, F. W. Taylor (time study) and F. and L. Gilbreth (motion study). ${ }^{3}$ However, an important contribution to the industrial health and efficiency debate was also made by the research organizations established by the British government during the crisis years of World War I and its aftermath, under the auspices of the recently created Medical Research Committee (MRC). The Industrial Health Research Board (IHRB) was formed in July 1918: "To consider and investigate

*A. J. McIvor, PhD, History Department, University of Strathclyde, McCance Building, 16 Richmond Street, Glasgow G1 1XQ.

I am indebted to the following for their comments on drafts and for help with sources: D. J. Oddy, D. Hamilton (Wellcome Unit, Glasgow), H. F. Gospel, and the archivists at the Medical Research Council Archives and the British Library, London.

${ }^{1}$ C. Webster, 'Healthy or hungry thirties?', History Workshop Journal, spring 1982, pp. 110-129; C. Webster, 'Health, welfare and unemployment during the depression', Past and present, 1985, 109: 204-230. See Webster's text and references for thorough bibliography of the health debate.

2 The recently published collection of essays by $P$. Weindling (editor), The social history of occupational health, London, Croom Helm, 1985, clearly identifies the neglect of this particular area and provides some rectification of a serious gap in the literature. The volume illustrates a need for much further research, particularly, it might be argued, regarding in-depth, regional/local case studies of occupational health, preferably with a comparative dimension.

${ }^{3}$ See F. W. Taylor, Scientific management, New York, Harper \& Row, 1947; F. B. Gilbreth, Motion study, New York, D. Van Nostrand, 1911; G. Cadbury, Experiments in industrial organisation, London, Longman, 1912; and the Report of the Interdepartmental Committee on Physical Deterioration, London, HMSO, 1904, pp. 28, 87, 123-124. See also G. R. Searle, The quest for national efficiency, Oxford, Blackwell, 1971, pp. 102-103. 
the relationship of the hours of labour and of other conditions of employment; including methods of work, to the production of fatigue, having regard both to industrial efficiency and to the preservation of health amongst the workers." 4

This essay examines the impact of work organization and the work environment on employees' health, focusing in particular on the origins and work of the IHRB from its formation (as the Industrial Fatigue Research Board) through the 1920s and 1930s. ${ }^{5}$ It is based largely on the surviving archives and reports of the Board, held by the Medical Research Council in London. Section I examines the genesis of the Board and the circumstances surrounding its formation and composition. Section II investigates the work of the Board, its orientation and role in the 1920s and 1930s. Finally, Section III analyses the dissemination of research findings and new ideas on industrial health and efficiency and relates this to general trends in work organisation, technological change, and health at work in the inter-war years.

The IHRB emerged from the experience gained in industrial health, efficiency, and the management of labour during World War I, with the mass influx of women workers into war industries. Before 1914, physiological and psychological health at work was severely neglected by the vast majority of British managers and employers, most of whom were concerned only to stay within the legal limits of the Factory Acts. ${ }^{6}$ Research into the scientific basis of industrial fatigue, efficiency, and health was only in its infancy, with the result that individual worker productivity was relatively poor, certainly in many cases far from achieving its full potential. ${ }^{7}$ This was the consequence partly of excessive energy expenditure at work, exacerbated by relatively poor general standards of health, as indicated in the Report of the Interdepartmental Committee on Physical Deterioration of 1904, which had been established to investigate the causes of the very high rejection rates of would-be army recruits on health and physique grounds during the Boer War.

It was the First World War, 1914-18, however, that really brought the debate on industrial health and efficiency into the public arena. Within a year of the first shots being fired, the British war effort was facing serious problems on the "home front" because the productivity of munitions workers was declining as a consequence of accumulated and in many cases chronic fatigue. Workers had commonly been engaged in a 75-85-hour working week over 1914-15, with little consideration for the long-term effects this would have on health or efficiency. By the summer of 1915, the government had recognized that serious deficiencies existed in wartime labour management and in September 1915 set up the Health of Munitions Workers'

\footnotetext{
${ }^{4}$ Industrial Fatigue Research Board, Annual Report, London, HMSO, 31 March 1920, p. 29.

5 For convenience and to avoid confusion in the text the initials IHRB are used throughout, whilst in the notes IFRB is used to 1928 (the year of the name change) and IHRB thereafter.

${ }^{6}$ M. M. Niven, Personnel management, 1913-63, London, Institute of Personnel Management, 1967, pp. $15-18$.

${ }_{7}$ Engineer, London, 14 November 1913, p. 521; J. A. Hobson, 'Scientific management', Sociol. Rev., 1913, 7: 198-199. For a general discussion of labour management in the pre-1914 period see C. R. Littler, The development of the labour process in capitalist societies, London, Heinemann, 1982, pp. 80-98.
} 


\section{A. J. McIvor}

Committee (HMWC) to investigate exhaustively the "laws" governing industrial health and efficiency.

Over a period of two years, the HMWC carried out a series of pioneering works studies, commissioning physiologists, psychologists, statisticians, medical researchers, and industrial hygiene specialists to undertake scientific experiments into aspects of industrial medicine, health, efficiency, and fatigue. In its findings the HMWC indicated a clear relationship between excessive working hours, a worker's "fatigue threshold", and declining productivity levels. The Committee also elaborated on the correlation between general working conditions-adequate illumination, ventilation, seating, washing, sanitary, and safety arrangements - and productivity levels, and also on the links between nutrition, environmental factors, and efficiency. ${ }^{8} \mathrm{~J}$. C. Bridge, Senior Medical Inspector of Factories, reflected some years later that this was a crucial phase in the evolution of industrial medicine: "During this period it was realised for the first time that conditions special to the occupation were not the only cause of industrial disease, but that other factors - fatigue, under-nourishment, and other conditions met with both inside and outside the time of employment-were as important in the production of illness as those produced by the materials handled."9

The primary object of the HMWC was to find the optimum working hours, general working conditions, and external environment to achieve the highest productivity standards for the war effort whilst preserving workers' health and well-being so as to sustain levels of effort over what was anticipated by 1915 to be a long emergency period. The government incorporated a number of the Committee's recommendations into its wartime labour management decisions - including reduced working hours and the abolition of Sunday working. Much of the Committee's research, however, remained relatively narrow in focus, its terms of reference being confined solely to the munitions industry. By 1917, a number of HMWC members and industrial health specialists were lobbying for the establishment of a much more broadly based research organization to investigate industrial health, preventive medicine, and worker efficiency on an economy-wide basis.

Therefore, on the disbandment of the HMWC at the end of 1917, the Medical Research Committee and the Department of Scientific and Industrial Research, with the active encouragement and financial backing of the Home Office, formed the Industrial Health Research Board (IHRB) to investigate industrial health and fatigue on more comprehensive lines by embracing all classes of work within its scope of research. Walter Fletcher, Secretary of the MRC, was responsible for most of the early organizational work. He immediately recognized that the composition of the new Board and the early stages of its work were crucial if good relations for the future were to be assured with both workers and employers. As he astutely noted in August 1918:

\footnotetext{
${ }^{8}$ See, in particular, the Health of Munitions Workers' Committee (HMWC), Final Report, Industrial health and efficiency, London, HMSO, Cd. 9065, 1918, and the 21 Memoranda printed by the HMWC. For an interesting analysis of one of the best-publicized munitions-related health problems see $\mathbf{A}$. Ineson and D. Thom, 'TNT poisoning and the employment of women workers in the First World War', in Weindling, op. cit., note 2 above, pp. 89-107.

${ }^{9}$ Annual Report of the Chief Inspector of Factories and Workshops, for 1932, Cmd. 4377, London, HMSO, 1933, p. 55. Hereinafter referred to as Factory Inspector's Report.
} 
"We shall certainly have to go 'canny' for some time at the beginning". ${ }^{10}$ The Board's initial sensitivity towards antagonizing the trade unions was clearly indicated when it refused to support the ongoing research of $\mathbf{H}$. M. Vernon into deliberate worker output restriction in the shipyards. ${ }^{11}$ Fletcher was also keen from the outset to ensure that no connexion was made between the emerging British "fatigue studies" school and the American scientific management movement, which tended, he asserted, towards exploiting workers with the object of maximizing profit margins, and to take a very mechanical, instrumental view of the workman as "only a human machine". ${ }^{12}$ In a letter to J. R. Clynes, Labour leader in Parliament, Fletcher elaborated on his own conception of what the orientation of the British "fatigue studies" group should be: "The study, rightly conceived, and its results rightly applied must bring, I am convinced, its chief benefits to the workers themselves. We must make every effort to start from the beginning in fullest sympathy with the workers, and we can do little or nothing without their help, both in the study and in its applications."13

Throughout 1918 and the early part of 1919, an interim committee of the Board was canvassing for suitably qualified members. A number of interested organizations suggested names. George Cadbury's Anti-Sweating League nominated Charles Renold-an indication of the esteem in which the enlightened firm of Renold \& Company was held. ${ }^{14}$ Renold, however, was not the final choice, for Fletcher preferred to invite a representative of Mather \& Platt, the Manchester engineering firm which had pioneered the study of industrial fatigue in the $1890 \mathrm{~s} .{ }^{15} \mathrm{E}$. Hopkinson, a director of Mather \& Platt and a junior partner of William Mather in his 48-hour week experiment, duly accepted a position on the Board. C. S. Sherrington, Professor of Physiology at the University of Oxford, was appointed chairman, ${ }^{16}$ and D. R. Wilson, Factory Inspector (later Chief Inspector), secretary. Other members were E. L. Collis, Talbot Professor of Preventive Medicine, Cardiff; W. L. Hitchens, chairman of Cammell Laird \& Co. Ltd; Kenneth Lee, director of Tootal Broadhurst Lee \& Co. Ltd; C. S. Myers, Director of the Psychological Laboratory, Cambridge (and, in 1920, founder of the National Institute of Industrial Psychology); T. M. Legge, HM Medical Inspector of Factories (since 1898); and R. R. Bannatyne and B. Wilson as Assessors from the Home Office and the Ministry of Labour respectively. ${ }^{17}$

Fletcher claimed that he intended to have some female representation on the Board, but confessed in January 1919 to difficulty in finding candidates with training in physiology or medicine and some familiarity with industrial work. ${ }^{18}$ This brought a PF 30.

${ }^{10}$ Letter, W. Fletcher to H. M. Vernon, 19 August 1918, Medical Research Committee (MRC) Archives,

${ }_{11}$ Letter, H. M. Vernon to W. Fletcher, 20 August 1918, ibid.

${ }^{12}$ Letter, W. Fletcher to J. R. Clynes, 7 January 1918, ibid., PF 20.

13 Ibid.

${ }^{14}$ Letter, National Anti-Sweating League to W. Fletcher, 8 January 1918, ibid., PF 26.

15 Letter, W. Fletcher to E. Hopkinson, 24 June 1918, ibid., PF 20.

${ }^{16}$ Sherrington was appointed because he was one of the foremost physiologists in Britain and because of his prior investigations into industrial fatigue for the War Office in 1914-18. He was also a very close personal friend of Walter Fletcher. See H. M. Sinclair, 'Sherrington and industrial fatigue', Notes Rec. R. Soc. Lond., 1984, pp. 91-104.

${ }_{17}$ Letter, G. Bellhouse to M. Delevingne, 1 July 1918, MRC Archives, PF 22.

${ }^{18}$ Letter, W. Fletcher to Lady Rhondda, 15 January 1919, ibid., PF 20. 


\section{A. J. McIvor}

torrent of criticism and nominations from women's representatives and groups, including Millicent Garret Fawcett's National Union of Women's Suffrage Societies, Lady Rhondda (who embarrassed the Board with a vitriolic letter in The Times), and the Medical Women's Federation. ${ }^{19}$ Dr Beatrice Webb and Mrs Strachey were among the suggestions. ${ }^{20}$ Fletcher responded by inviting Mona Wilson and Winifred Cullis, both of whom accepted and joined the Board in the spring of 1919. Cullis was professor of physiology at the University of London and Wilson was known for her pre-war work as secretary of the Women's Trade Union League and for a number of works including Report on housing and industrial conditions (1905) and (with E. G. Howarth) West Ham: a study in social and industrial problems (1907). ${ }^{21}$

Consequently, the ultimate composition of the IHRB was similar to the HMWC, combining representatives of the universities, industry, the Factory Inspectorate, the MRC, the Home Office, and the Ministry of Labour. Despite Fletcher's sensitivity towards trade union support, official union representation on the Board was minimal, and this may have exacerbated the suspicion of the labour movement towards its work. In 1924, this oversight was corrected to a degree with the appointment to the Board of Arthur Pugh, General Secretary of the Iron and Steel Trades Federation, succeeded by Ernest Bevin (Transport and General Workers' Union) and Richard Coppock (National Federation of Building Trade Operatives) in the 1930s.

The Board underwent other changes in its composition throughout the inter-war period. With reorganization in 1920-1 and the MRC assuming full control, Sherrington resigned, and William Graham, who was a member of the MRC and an Edinburgh Labour MP, was appointed chairman. Graham was succeeded as chairman by Viscount D'Abernon (1926-9), financier, diplomat (first ambassador to Weimar Germany), and, in 1929, chairman of the MRC. A Conservative MP with an army background, Lt-Col. Sir Arnold T. Wilson, took over the chair 1929-33. He was replaced by a man who was probably the most able of IHRB chairmen, Professor E. P. Cathcart, an industrial specialist, applied physiologist and Regius Professor of Physiology at Glasgow University. Some continuity regarding the Board's work was achieved through the work of the secretary. The inter-war period is divided almost equally between the secretaryship of D. R. Wilson (1918-30) and Air-Vice-Marshal Sir David Munro (1930-42). Wilson was a Factory Inspector (later, Chief Inspector, 1932-40) and a specialist in illumination and humidity; Munro had been Director of Medical Services, RAF. As far as the general composition of the Board is concerned, there was a fairly rapid turnover of personnel, none of the original Board, for example, remained in 1930. However, the mix of interests seems to have remained fairly constant. Apart from Cathcart, Munro, and Bevin in the late 1930s, the Board included Sir F. J. Marquis (politician and businessman, managing director of Lewis's), Hilda Martindale (Factory Inspectorate), Professor C. Burt (London psychologist), Professor F. C. Bartlett (Cambridge psychologist), C. G. Douglas (Oxford

\footnotetext{
${ }^{19}$ Ibid. See also letter, National Union of Women's Suffrage Societies (NUWSS) to W. Fletcher, 30 January 1919; and letter, J. Walker to W. Fletcher, 3 February 1919, ibid., PF 20.

${ }^{20}$ Letter, NUWSS to W. Fletcher, 17 February 1919, ibid.

${ }^{21}$ Letter, W. Fletcher to W. Cullis, 25 March 1919, ibid. S. Lewenhak, Women and trade unions, London, Benn, 1977, pp. 114, 117, 127.
} 
physiologist) and Professor W. W. Jameson (preventive medicine specialist and first Professor of Public Health at the London School of Hygiene and Tropical Medicine, 1929).

Whilst the Board determined policy and direction, a cadre of professional investigators undertook the detailed empirical research into health, efficiency, and industrial fatigue. Here the links with the HMWC were close, as a number of the Committee's field workers and researchers, including H. M. Vernon, Professor T. Loveday, and A. F. Stanley Kent, transferred their services to the IHRB, usually on a part-time basis, as many held permanent academic posts. By 1920, the investigating staff of the Board numbered twenty-five, supported by eleven clerks and several secretaries. 22

The role of the IHRB was to study scientifically the human factor in industry and particularly the health and efficiency problems created by modern industrial conditions and technological change. ${ }^{23}$ It was not in the business of maximizing productivity for its own sake, at any cost, as some of its detractors argued ${ }^{24}$ but rather to discover, through scientific analysis, precise work measurement, and calculations of energy expenditure at work, the optimum conditions and methods of work for the operatives. This, both the Board and the Factory Inspectorate argued, provided common benefits for employers and workmen. ${ }^{25}$ It also involved a search for the easiest, most energy-conserving methods of work, rather than necessarily the quickest, and brought the Board into conflict with the American-inspired maximizing efficiency engineering school of thought. Indeed, as a component part of the "human factor industrial psychology" school, the board was responsible for the exposure of what Rose has called "the scientific crudity of Taylorism". 26

The IHRB was inspired by the wastage that arose from the indifference shown in Britain towards physiological and psychological aspects of industry, and the ignorance of the principles governing the healthy employment of the human mind and body. It was pointed out that over ten times as much production time was lost through sickness-much of which was preventable - as was lost through strikes and disputes. ${ }^{27}$ Research in this area thus had enormous potential. The philosophy of the Board from its earliest days was that "maximum production is contingent on maximum fitness on the part of the worker". ${ }^{28}$ However, in essence, it was a fact-finding research body formed to acquire and accumulate scientific knowledge and was not directly involved in policy decision-making, as it made clear in its first Annual Report: "The object of

22 IFRB, Annual Report, 31 March 1920, pp. 9-10.

${ }^{23}$ Editorial by R. Calder, 'New dangers of the machine', Daily Herald, 19 March 1934.

24 IHRB, Annual Report, 30 December 1928, pp. 22-23; ibid., 30 June 1934, pp. 3-4.

25 IFRB, Annual Report, 30 September 1921, p. 43; ibid., 31 December 1928, p. 18; Factory Inspector's Report, 1932, Cmd. 4377, p. 9.

${ }^{26}$ M. Rose, Industrial behaviour, Harmondsworth, Middlesex, Penguin, 1978, pp. 65-66, 84-85.

${ }^{27}$ IFR B, Annual Report, 31 December 1924, p. 27; T. Burt, 'Waste in human power', Oxford Lecture Conferences for Works Directors Managers etc., (London School of Economics Library), 22 April 1923, pp. 38-39. Hereinafter referred to as Oxford Lecture Conferences.

${ }^{28}$ IFRB, Annual Report, 31 December 1924, p. 26. 


\section{A. J. McIvor}

the Board is to obtain exact facts about fatigue caused by industrial employment in different trades and under different conditions in the same trade, but the Board is not itself concerned with the alteration of existing conditions by legislation or otherwise. The results obtained will be published, and then it will be possible for persons employed and others interested to make any suggestions they think necessary for improved conditions when they have weighed the facts."29 Noting, however, the crucial need for practical verification of the Board's findings, employers were encouraged to commit themselves to extended scientific investigation within their companies to improve labour health and efficiency. ${ }^{30}$ The stimulation of the habit of experimentation was thus considered to be one of the main objects of the IHRB.

The work of the Board involved a mix of field-work at the workplace and laboratory research. It responded to requests from individual industries to investigate labour efficiency and health, and elaborated general principles and hypotheses relating to the causation, measurement, and incidence of industrial fatigue. It concentrated almost solely on the workplace. Unlike the HMWC, the Board did not investigate external factors - economic, dietary, social, or educational-which were known to influence health and industrial efficiency. However, several investigations were taken over from the HMWC, and a number of new initiatives undertaken on request from employers or suggestions from the government. Representatives of Joint Industrial Councils, employers' associations, industrial research associations, and trade unions, together with one of the specialist Factory Inspectors, would usually form a sub-committee to advise on technical points and criticize or comment on the research progress of the Board's investigators working in their particular industry. ${ }^{31}$ Indeed, the Board encouraged the permanent establishment of such joint committees in all industries to discuss questions of industrial health and efficiency and medical research transmitted by the IHRB. This anticipated network of special industry-wide committees proved, however, to be an ideal that never fully materialized in the 1920s and 1930s.

The emphasis of the IHRB's work altered in response to circumstances, as the early years were fraught with disruptions. The Board was formed at a time when excessively long hours were still being worked during wartime (though the position was much improved in comparison to 1914-15) and when there was much subjective evidence of extreme fatigue. No sooner, however, had a number of investigations on the incidence of industrial fatigue got under way, than the war ended in November 1918, and in its aftermath, working hours were almost universally reduced to around 47-48 per week. ${ }^{32}$ The brief post-war replacement boom gave way to a severe recession, which set in during the winter of $1920-21$. This not only precipitated a reduction in the financial budget of the Board - as part of the government's economy drive-but led to further disruptions, caused by extensive lay-offs and short-time working in industry, shorter standardized production runs (essential for research purposes), and a tendency amongst employers and workers to become preoccupied with internal problems and

29 Ibid., 31 March 1920, p. 27.

30 Ibid., 31 December 1923, pp. 21-22.

31 Ibid., 31 March 1920, pp. 10-11.

32 Ibid., 31 September 1921, p. 5. 
less willing to co-operate in the work of the IHRB ${ }^{33}$ The depression continued to affect the work of the Board adversely throughout the 1920s and 1930s.

Nevertheless, up to 1939 the Board produced eighty-four special research monographs and numerous articles in the academic and medical press. These significantly extended the theoretical knowledge in Britain of the "human factor" in industry (which had been largely confined to the munitions/engineering industry) and indicated, using scientific analysis in a number of different industries and occupations-including textiles, metals and engineering, mining, boot and shoe, printing, pottery, laundries, and the leather trade - that productivity was closely related to the health of the workers. The IHRB started with investigations into the hours of labour and the working environment, moved into analyses of methods of work, job design, and vocational psychology, and, by the later 1930s, concentration was increasingly laid on specific medical topics (including occupational disease).

The false economy of working over a certain number of hours, depending on the mental and physical strain involved in performing the task, was clearly shown by H. M. Vernon in his pioneering work for the HMWC. Vernon and other IHRB investigators continued this project by elaborating, for a range of tasks and occupations, the optimum working hours. Vernon's methods were to chart hourly output curves by some form of recording production (for example, the use of automatic pick recorders on looms), identify the incidence of worker fatigue, and eliminate this as far as possible by experimenting with shorter hours, rest pauses, and improved working methods and conditions, the result of close analysis of the labour process, the technology employed, and the ways in which energy was expended on the job. ${ }^{34}$ Organized and systematic rest pauses were one way to arrest the onset of industrial fatigue. On machine and conveyor operations, for example, it was found that a pause of five minutes each hour was a far more efficient method than a 10-15 minute tea break in the middle of the work spell. ${ }^{35}$

The IHRB also publicized the idea that workers' bodies were highly sensitive to changes in temperature, humidity, noise, and light and that these could have an extremely variable effect on efficiency. In a number of investigations into fine and very detailed work, the Board calculated the appropriate levels of illumination according to the size of the detail to be distinguished. Researchers found that in silk-weaving, for example, productivity was reduced by up to ten per cent where artificial rather than natural light was used. ${ }^{36}$ One solution suggested by the Board was the use of slightly magnifying spectacles for such categories of work. ${ }^{37}$

\footnotetext{
33 Ibid., 31 December 1922, pp. 4-5.

34 Ibid., 30 September 1921, pp. 26-29. See also H. M. Vernon, 'The influence of hours of work and of ventilation on output in tin manufacture', IFRB Report No. 1, London, HMSO, 1919; H. M. Vernon, 'Fatigue and efficiency in the iron and steel industry', IFRB Report No. 5, 1920; and H. M. Vernon and T. Bedford, 'Rest pauses in heavy and moderately heavy industrial work', IFRB Report No. 41, 1927.

35 IHRB, Annual Report, 30 June 1938, pp. 5-6.

${ }^{36}$ IFRB, Annual Report, 30 September 1921, pp. 42-43; P. M. Elton, 'A study of output in silk weaving during the winter months', IFRB Report No. 9, 1920, p. 55.

${ }^{37}$ H. C. Weston and S. Adams, 'Further experiments on the use of special spectacles in very fine processes', IHRB Report No. 57, 1929, pp. 23-26.
} 


\section{A. J. McIvor}

Similarly, the Board developed, through scientific investigation and measurement, a comprehensive range of data on the best temperatures, humidity levels, and air speeds to produce the highest productivity levels for different occupations and processes. This work was pioneered by S. Wyatt, A. B. Hill, H. M. Vernon, and T. Bedford, using various instruments such as the kata-thermometer, developed by Sir Leonard Hill to measure the combined effects of temperature and air velocity. Research concentrated on the hot, heavy industries, including the iron, steel and tinplate trades, coal-mining, and cotton-weaving. ${ }^{38}$ Some of the results indicated enormous wastage. In mining, there was found to be up to a forty-one per cent loss of efficiency in hot and poorly ventilated shafts, whilst in one iron and steel works, twelve per cent less was produced on average in summer than in winter because there was no artificial ventilation. ${ }^{39}$ In cotton-weaving, an investigation of the records of 10,000 weavers in "steamed" sheds compared to 10,000 in "dry" sheds indicated that whilst excessive steaming may have reduced individual efficiency, there was no correlation between sickness incidence and workers' exposure to "normal" levels of steam. ${ }^{40}$ The statistical basis of the inquiry was such that both the unions and the employers accepted this as the definitive answer to a question that had caused much controversy in the industry. ${ }^{41}$ On the other hand, the Board did find that in other occupations, atmospheric conditions had a considerable influence on both sickness- and accident-proneness. Steel-smelters, puddlers, and pitmen in the iron and steel trades lost twenty-two per cent more time than the average in their industry due to sickness. Accident-proneness, it was also found, increased considerably in colder temperatures, due to a loss of manual dexterity. ${ }^{42}$

Vibration, dust, and noise were also the subject of investigation in an attempt to indicate the relationship between such variables and labour productivity. All had adverse effects in varying quantities, and as a result the Board championed their elimination in the workplace, or protection against them in the form of localized dust-extractor systems and ear-protectors. In cotton-weaving, using the traditional Lancashire looms, eight per cent more production on average was forthcoming when ear-protectors were used, which eliminated around fifty per cent of the noise. ${ }^{43}$ One important finding was the considerable variation in each individual's reaction to noise, depending, the Board hypothesized, on the particular psychological make-up of the individual. A. B. Hill also followed up his statistical inquiry into artificial humidity in cotton-weaving with a similar investigation into the relationship between inhaling cotton dust in the cardroom (where preparatory processes prior to spinning took place) and respiratory disease. His results indicated clearly the extremely dangerous

${ }^{38}$ See the IFRB Reports, Nos. 21, 37, 39, 46, 48, 60, and 76.

39 IHRB, Annual Report, 30 June 1938, pp. 15-16.

${ }^{40}$ Ibid., p. 35. See also A. B. Hill, 'Artificial humidification in the cotton weaving industry', IFRB Report No. 48,1927 , p. 72.

${ }^{41}$ For example, see the debate in the Cotton Spinners' and Manufacturers' Association, Joint Minutes (with the Amalgamated Weavers' Association), 16 March 1906.

${ }_{42}$ IFRB, Annual Report, 30 September 1921, pp. 37-8; IHRB, Annual Report, 30 June 1938, pp. 17-18.

${ }^{43} \mathrm{H}$. C. Weston and S. Adams, 'The performance of weavers under varying conditions of noise', IHRB Report No. 70, 1935, p. 14.

44 A. B. Hill, 'Sickness amongst operatives in Lancashire cotton spinning mills', IHRB Report No. 59, 1930, pp. 77-79. See also Factory Inspector's Report, 1930, Cmd. 3927, p. 95. 
and unhealthy environment of the cardroom, where the workers suffered three times as much respiratory disease as workers in other departments. ${ }^{44}$

The research interests of the Board in the 1920s tended to shift from hours of work and environmental conditions to methods of work, job design, and vocational psychology, aspects more closely related to the scientific management movement of the American "efficiency engineers", like F. Taylor and F. Gilbreth. The Board pioneered vocational guidance and performance testing in Britain-both physiological and psychological-developing techniques to ensure that workers were placed in the occupations for which they were best fitted. Being a "misfit", with no inherent capacity to perform the work task, lowered a worker's "fatigue threshold" and was detrimental to health, so vocational selection and training were seen to offset overstrain. ${ }^{45}$ There was, moreover, much evidence of workers being physically unsuitable not only for recruitment into the armed forces, but also for particular work tasks. Professor E. P. Cathcart undertook a statistical inquiry for the IHRB into the weight, height, and strength of over 10,000 men in $1933-4$, the most comprehensive investigation into physique since the infamous wartime Ministry of National Service C3 Report of 1917-18. ${ }^{46} \mathrm{He}$ found invariably the smallest men doing the heaviest jobs, a phenomenon reported in the Daily Worker under the headline 'Small Men do the Big Jobs' in March 1934. ${ }^{47}$ The Board (in conjunction with the National Institute of Industrial Psychology) pioneered the cataloguing of various occupations according to the aptitudes and capacities required in them, and the examination and testing of applicants with a view to advising them of the kind of employment to which they might be "naturally" fitted. This work was largely undertaken by E. Farmer, May Smith, and B. Muscio on printing compositors, engineering workers, telegraphists, and confectionery employees. ${ }^{48}$ In the latter case, it was discovered that the size and shape of the workers' hands largely determined productivity in a number of sweetproduction processes. ${ }^{49}$ Moreover, the principles of vocational selection could be applied to improve supervisory and managerial personnel, the calibre of which was often criticized by the Board: "If selection and training are needed anywhere, they are needed for management". 50

The commitment of the Board to improving methods of work and job designs was indicated by their early utilization of time and motion studies. The explicit aim of such studies was to identify and measure obstacles to easy performance of the work task and thus to reduce needless energy expenditure and consequently relieve the physical and mental strain of work. C. S. Myers and E. Farmer were responsible for these investigations at the Derwent Iron Foundry, an anonymous metal polishing workshop, and Pascall's confectionery company, while S. Wyatt undertook a number

\footnotetext{
${ }^{45}$ B. Muscio and E. Farmer, 'Three studies in vocational selection', IFRB Report No. 16, 1922, pp. 66-67.

46 E. P. Cathcart, D. E. R. Hughes, and J. G. Chambers, 'The physique of man in industry', IHRB Report No. 71, 1935; IHRB, Annual Report, 30 June 1935, pp. 15-16.

47 Daily Worker, 20 March 1934.

48 IFRB, Annual Report, 30 September 1921, pp. 47-49. See Muscio and Farmer, op. cit., note 45 above, and M. Smith, M. Culpin, and E. Farmer, 'A study of telegraphists' cramp', IFRB Report No. 43, 1927.

${ }^{49}$ IFRB, Annual Report, 30 September 1921, pp. 48-9; Muscio and Farmer, op. cit., note 45 above, pp. $85-86$.

${ }^{50}$ IHRB, Annual Report, 30 June 1936, p. 3.
} 


\section{A. J. McIvor}

of studies in textile plants, and M. Smith an investigation of laundries. ${ }^{51}$ The Board laid great emphasis on the advantages to be derived from closely studying the labour process, formulating a set of the most efficient movements for each task, rationalizing the arrangement of tools and materials, studying the design of machinery, and carefully training workers in the improved methods of doing the job. ${ }^{52}$ Optimum loads and the best working height of the bench were also calculated. The Board advocated close union co-operation during any work measurement exercise and an equitable wage incentive scheme; that is, one that did not incorporate an automatic pricebreaker, as the premium bonus system did. ${ }^{53}$ The latter was particularly dangerous for weaker workers, who spurred themselves on, often into serious overstrain. ${ }^{54}$ As Vernon argued, one of the most frequent causes of excessive fatigue in the 1920s was the speeding-up tendencies of unsuitable systems of remuneration. ${ }^{55}$

The potential for increased productivity with reduced energy expenditure and improved health using such methods was clearly realized, and the IHRB postulated that if such scientific management methods were introduced in a fair and just manner, with the object of improving work methods and reducing energy expenditure, rather than simply "speeding-up" work, then the benefits for both management and men were enormous. 56 The problem lay in the application of such concepts. The IHRB investigators claimed never to have used the stop-watch to set "standard" times for tasks, nor, as the efficiency engineers used them, with a view to necessarily increasing output. ${ }^{57}$ Nevertheless, workers were particularly suspicious of this aspect of the Board's work, regarding it as an unwarranted monitoring procedure, an interference and a humiliation, and a first step to speeding up production. ${ }^{58}$ In fact, the Board spoke out on a number of occasions against the intensifying pace of work which characterized much of inter-war industry.

The Board developed, in conjunction with a number of other organizations-most prominent of which was the National Institute of Industrial Psychology-a vitriolic critique of the methods of what they regarded as the "pseudo-scientific" Americaninfluenced managerial school, and advocated a peculiarly British brand of labour management, more "humanized" and based firmly on the empirical findings of the more purely scientific "fatigue studies" and industrial psychology investigations. 59 The crucial point stressed by the IHRB was the great diversity of human physical and

${ }^{51}$ C. S. Myers, 'A study of improved methods in an iron foundry', IFRB Report No. 3, 1919; E. Farmer, 'Motion study in metal polishing', IFRB Report No. 15, 1921; S. Wyatt, 'Variations in efficiency in cotton weaving', IFRB Report No. 23, 1923; M. Smith, 'Some studies in the laundry trade', IFRB Report No. 22, 1922.

52 IHRB, Annual Report, 30 June 1935, pp. 15-16; 30 September 1921, p. 49.

53 Ibid., 30 June 1937, p. 3; E. Farmer, 'Time and motion study', IFRB Report No. 14, 1921, p. 20.

54 S. Wyatt, L. Frost, and F. G. L. Stock, 'Incentives in repetitive work', IHRB Report No. 69, 1934, pp. 56-57.

${ }_{55}$ IFRB, Annual Report, 31 December 1924, pp. 56-57.

${ }^{56}$ IHRB, Annual Report, 30 June 1938, p. 38.

57 Farmer, op. cit., note 53 above, p. 34 .

58 IHRB, Annual Report, 30 June 1934, pp. 3-5. Many workers had a justified phobia about medical examinations and output measurements, especially as they became older. It was widely rumoured that the results would go down as a black mark in a worker's file and be used against him or her later, as an excuse for dismissal when work was slack. The spectre of unemployment, above all, fuelled workers' suspicions and prejudices. See J. E. Cronin, Labour and society in Britain, 1918-1979, London, Batsford, 1984, pp. 35-6. 


\section{Manual work, technology, and industrial health 1918-39}

mental capabilities and the considerable variety in different people's energy levels. ${ }^{60}$ This was the basis of its labour management philosophy. Workers should preferably be allowed to control their own speed of work and make adjustments to their pace as and when the chose: "The work of the human machine cannot be ticked out in seconds as by a clock. It has rhythm, and the rhythm varies-work has its ups and downs-in tune to the pulse of physical and mental energy, which itself rises and ebbs in accordance with the physiological laws governing the functions of all living organisms."61 $\mathrm{E}$. Farmer argued that the question of rhythm was all-important. Fatigue resulted when effort norms were excessively increased because of the interference generated with the natural rhythm of the body. ${ }^{62}$

As far as the labour process is concerned, it would be a fair generalization to state that the trend in industry in the inter-war period with the shift in emphasis from the older, declining staple industries, to the newer, more prosperous industries was towards more mechanized, uniform, sub-divided, light, repetitive work which placed a premium on dexterity and mental capacity, rather than muscle. The Chief Medical Inspector of Factories noted in 1935: "Speed is the essence of present day industry, as exemplified in the conveyor system . . . wherein a single operation is performed, minute in and minute out, throughout the working day. It is too early yet to judge of the results of this system on the health of the workers so employed, but some apprehension cannot but be felt as to its ultimate effects." ${ }^{\text {"63 }}$ The IHRB consequently devoted its energies to investigating the psychology of work, and particularly the problem of monotony, producing a whole series of reports incorporating the results of their surveys into light, repetitive work. ${ }^{64}$ In general, they found that efficiency was seriously impaired by lack of job satisfaction, resulting commonly in a loss of 10-30 per cent of potential output and a decrease in the quality of work. ${ }^{65}$ As an antidote to monotony-defined as the flagging of mental energy, expressing itself in a feeling of apathy and lassitude - the Board suggested specific changes in work design to increase interest, rotation of the most simple tasks at intervals rather than specialization, psychological and physiological selection tests to find the most suitable personnel, shorter working hours, more frequent rest pauses and breaks, and, finally, music piped into the workplace. ${ }^{66}$ Piece-rate working was considered an essential incentive for repetitive work, though Wyatt, Frost, and Stock found in 1934 that such payment systems could have adverse side-effects (including increased jealousy, strained relations, and irritability), especially

\footnotetext{
${ }^{59}$ See, for example, Sir David Munro, secretary of the IHRB, 'Introduction to the 38th Oxford Management Conference on Optimum Productivity in Modern Industry', British Management Review, III, no. 3, July-September 1938, pp. 10-24.

${ }^{60}$ E. Farmer, 'The practical uses of time study', Oxford Lecture Conferences, 1 October 1926, p. 11. See also Smith, Culpin, and Farmer, op. cit., note 48 above; and Rose, op. cit., note 26 above, pp. 79-80.

${ }^{61}$ IHRB, Annual Report, 30 June 1937, p. 3.

62 IFRB, Annual Report, 30 September 1921, p. 54.

${ }^{63}$ Factory Inspector's Report, 1935, Cmd. 5230, p. 42, cited in N. Branson and M. Heinemann, Britain in the nineteen thirties, St Albans, Panther, 1973, p. 95.

${ }^{64} \mathrm{See}$, for example, S. Wyatt and J. A. Fraser, 'The effects of monotony in work', IHRB Report No. 56, 1929; and S. Wyatt and J. N. Langdon, 'Fatigue and boredom in repetitive work', IHRB Report No. 77, 1937.

65 IHRB, Annual Report, 30 June 1932, p. 20.

66 Ibid., pp. 21-22; 30 June 1938, pp. 24-26. See also C. S. Myers, 'Industrial overstrain and unrest' in B. Muscio (editor), Lectures on industrial administration, London, Pitman, 1920, pp. 175-177, $181-182$.
} 


\section{A. J. McIvor}

affecting the slower and less capable operatives. ${ }^{67}$ In other words, incentives prolonged effort but at a cost: "At the same time it is often responsible for undesirable forms of behaviour and may be the cause of much unhappiness. It stimulates the selfish and assertive tendencies in human nature and while the more capable workers find this pleasant and satisfying, those who are less well endowed may become discouraged and depressed." 68

The emphasis in the Board's work shifted in the 1930s to an analysis of a range of psychological problems related to work and, through their links with the MRC, the Board made a number of inquiries into specific medical problems of health at work. A. B. Hill's cardroom dust and respiratory diseases investigation falls into this category. ${ }^{69} \mathrm{He}$ also undertook two other statistical inquiries into the incidence of tuberculosis in the printing trade and the excessive prevalence of gastric sickness amongst bus-drivers. ${ }^{70}$ In the late 1930s, the IHRB was also involved in two other related research projects; the effects of inhaling toxic industrial solvents and psycho-neurosis in industry. ${ }^{71}$

One of the Board's significant failures, however, was their inability to perfect any reliable psychological or physiological test to determine and precisely to measure industrial fatigue. Immediately prior to and during World War I, a number of industrial health investigators (including A. F. Stanley Kent) had felt confident that using a number of gadgets to test strength, dexterity, mental alertness, reflexes, blood pressure, and pulse rate, an adequate scientific test to indicate fatigue could be formulated. Such tests, at least in their early unsophisticated form, were all described by B. A. McSwiney (lecturer in applied physiology, Leeds University), B. Muscio (IHRB investigator), and a number of other researchers who were increasingly experiencing difficulties using such techniques. ${ }^{72}$ The main problem, as Muscio noted, was the impossibility of eliminating curiosity, emotion, and will in the subject being tested. $^{73}$

As a result, the Board fell back on the use of indirect measurements of fatigue, particularly concentrating throughout the 1920s and 1930s on the use of an output norm or performance test as a retrospective indicator of fatigue. ${ }^{74}$ Other indices were used as corroborating evidence, including time lost, sickness, accident, mortality, and labour turnover rates. The use of the output test was considered most satisfactory but it did result in some limitation of the Board's research work. Such a test could only be applied to uniform production processes where output was relatively standardized and

${ }^{67}$ Wyatt, Frost and Stock, op. cit., note 54 above, p. 57. See also Lewenhak, 1977, op. cit., note 21 above, pp. 212-213.

${ }^{68}$ Wyatt, Frost, and Stock, op. cit., note 54 above, p. 49.

${ }^{69}$ Hill, 1930, op. cit., note 44 above.

70 A. B. Hill, 'An investigation into the sickness experience of printers', IHRB Report No. 54, 1929; 'An investigation into the sickness experience of London Transport workers', IHRB Report No. 79, 1937. For Bevin's critical comments on the delay (1928-37) regarding the latter report see E. Bevin, The job to be done, London, Heinemann, 1942, p. 169.

71 IHRB, Annual Report, 30 June 1938, pp. 31-34, 38.

72 Letter, B. A. McSwiney to IFRB, 27 January 1920, MRC Archives, 2080; B. Muscio, 'Is a fatigue test possible?', Br. J. Psychol., 1921, no. 10, part 1.

${ }_{73}$ IFR B, Annual Report, 31 March 1920, pp. 13, 18-21.

${ }^{74}$ Munro, op. cit., note 59 above, p. 6. 
thus could be precisely measured-as in weaving or in shell-making. The sensitivity of the output test for fatigue depended also on the nature of the work and particularly the extent to which the human factor played a part in the production process. Obviously, in predominantly automatic processes, output changes are an unsuitable test for human fatigue. Moreover, much care had to be exercised on the part of the investigators to eliminate other factors that might be responsible for output variations, including forms of incentive, technical adjustments, and material flows, and the deliberate output restriction or improvement by workers who might have a vested interest in slanting the results of the experiment one way or the other. The reports of the Board indicate that its investigators were acutely aware of such pitfalls, and that they went to considerable lengths to eliminate, or at least make allowances for, all other possible factors influencing output performance.

\section{III}

How far did the IHRB succeed in getting across to British industry its message that industrial medicine pays? Did its influence, in conjunction with the thrust of technological change, rationalization of the labour process, and related developments, result in an improvement in industrial health during the inter-war years? These are difficult questions to address and our conclusions are necessarily tentative, partly because vital evidence is lacking and partly because of the difficulties involved in disentangling ideology from actual workshop practice. ${ }^{75}$ It was one thing to express interest in innovative labour management ideas, quite another to implement such a system on the shop floor. As Paul Weindling has recently commented: "The gap between awareness of hazards and effective action to eliminate the danger is a recurrent feature of the history of occupational health". ${ }^{76}$

There were a number of mechanisms by which the work of the IHRB percolated through to industry. Its findings were marketed in the form of highly technical, academic research monographs through HMSO, and its researchers also used the medical and growing labour management press to present their arguments and hypotheses. However, a number of independent organizations were largely responsible for the practical diffusion of the "fatigue studies" ideology. Here, the National Institute of Industrial Psychology (NIIP) was an important link. The NIIP was established by the pre-eminent industrial psychologist in inter-war Britain, Charles Myers, who left his post as director of the Psychology Laboratory at Cambridge to head the new institute. The NIIP was established as a commercial enterprise in 1921, funded by private fees and contributions, to provide a consultancy service for firms interested in improving productivity. ${ }^{77}$ Myers was critical of the American "efficiency

\footnotetext{
${ }^{75}$ The lack of regular workplace medical inspection in the 1920s and 1930s means that there is no way of analysing statistically the precise impact of occupation on health. See Factory Inspector's Reports, 1933, Cmd. 4657, p. 49; 1934, Cmd. 4931, p. 51; 1936, Cmd. 5514, p. 42. There are also problems using the Factory Inspector's aggregated statistics on accidents, poisoning, etc., as the basis for data collection was continually changing and improving, and the fluctuating numbers employed or partially employed in the depression years makes year-by-year comparisons most unreliable.

${ }^{76}$ Weindling, op. cit., note 2 above, p. 16.

${ }^{77}$ IFRB. Annual Report, 31 December 1924, p. 22; Report on Proposed Relations Between the IFRB and the NIIP, 29 November 1920, MRC Archives, File No. 2080; Manchester Guardian, 28 March 1922, p. 8.
} 
engineering" approach to labour management and of employer-initiated welfare schemes, such as that operating at $\mathrm{ICI} .^{78} \mathrm{He}$ advocated the application of psychological investigation and knowledge to the problems of industry and industrial relations, this to be done with the fullest consultation of the workers themselves. ${ }^{79}$

Though they had their differences, relations between the IHRB and the NIIP were close throughout the 1920s and 1930s, and the Institute played a significant, if not crucial, role in disseminating the ideas of the Board ${ }^{80}$ Myers was both a member of the Board and the director of the NIIP in the 1920s and '30s. Arrangements were made by the Board in 1921 for complete co-operation and free interchange of investigators with the Institute. ${ }^{81}$ This arrangement worked well to provide Board investigators with fieldwork experience in individual factories, and Institute researchers with laboratory facilities, and thus to provide the closest intimacy between pure and applied research. The Board advertised the services of the NIIP in its reports and monographs, whilst the Quarterly Journal of the NIIP provided a forum for a précis of the Board's research findings and ongoing work, often with some discussion of the possible practical applications. ${ }^{82}$ Moreover, the debt of the Institute to the pure research undertaken by the Board was recognized by Myers and was indicated clearly in a number of the NIIP's publications. In a collection of articles by NIIP researchers edited by Myers in 1929, for example, forty per cent of the references cited in the bibliography were IHRB or HMWC publications. ${ }^{83}$ The Institute continued to develop through the 1920s and 1930s and was responsible for the practical dissemination of the Fatigue Board's findings as well as encouraging the idea of scientific-based experimentation into industrial efficiency and health. ${ }^{84}$ As the Board recognized: "It conducts for individual firms practical investigations into the way in which human energy is being used, such as time and motion studies, routing and lay-out investigations, surveys of hours of work and of environmental factors such as heating, lighting and ventilation etc., and by doing so is enabled to recommend in practice the adoption of measures based not only on the results of its own investigations, but on the more general results of the research work of the Board." 85

Some representation was also sought by the IHRB at a number of conferences and seminars, though it certainly did not seek a high profile. Hence, Sir David Munro's introductory address to the 38th Oxford Management Conference on Optimum Productivity in Modern Industry in 1938 was commented on as a rare appearance (and a great privilege!) by the IHRB secretary. Munro proceeded with a vituperative attack

${ }^{78}$ C. S. Myers (editor), Industrial psychology, London, Thornton Butterworth, 1929, pp. 10-11; C. S. Myers, Mind and work, London, University of London Press, 1920, passim; L. Urwick and E. F. L. Brech, The making of scientific management, London, Management Publications Trust, 1946, vol. 2, p. 223.

${ }^{79}$ G. Brown, Sabotage, Nottingham, Spokesman, 1977, p. 214; W. Raphael, 'The contribution of industrial psychology to personnel work', British Management Review, II, No. 2, April-June 1937.

80 IHRB, Annual Report, 30 June 1936, p. 31.

81 IFRB, Annual Report, 31 September 1921, p. 13.

82 Publications Department, MRC Archives, File No. 1111, 27 June 1922; IHRB, Annual Report, 30 June 1932, p. 45.

${ }^{83}$ Myers (editor), op. cit., note 78 above, pp. 245-249.

84 For a detailed analysis of the history of the NIIP see D. C. Doyle, 'The history of industrial psychology in Britain: the NIIP, 1921-39', Manchester University, PhD thesis, 1979.

${ }^{85}$ IHRB, Annual Report, 30 June 1932, p. 45. 
on the efficiency engineers' labour management techniques. The more enlightened participants of the Oxford Management Conferences organized by Rowntree had almost certainly read many of the Board's monographs and registered a continuing interest in its work. ${ }^{86}$ Moreover, the reports of such conferences indicate that the questions of fatigue, industrial health, and energy expenditure at work were often on the agenda.

The work of the Board also found a place in the discussions of the Management Research Groups (MRGs) in the late 1920s and the 1930s, and Harry Ward, the secretary of Group No. 1, received copies of the Board's research monographs. ${ }^{87}$ The MRGs were established in 1927 and were the inspiration of B. S. Rowntree, with C. G. Renold and L. Urwick being prominent in the movement in its early days. ${ }^{88}$ The idea was to establish a number of groups "to promote the efficiency of management in commerce and industry through the encouragement of the study of management problems, the exchange of experience between firms and organisations, and the provision of information". ${ }^{89}$ MRG 1 consisted of a number of the largest companies in Britain. MRG 2 combined companies employing between 500-2,000, and a number of other MRGs (eight in 1929) combined companies in relatively close geographical proximity in the main industrial regions. Total membership in 1929 was ninety firms, including, in MRG 1, such industry leaders as the Austin Motor Company, Dunlop Rubber, Imperial Tobacco, Lever Brothers, Rowntree \& Co., English Electric Co., Bradford Dyers Association, J. \& J. Colman, Pilkington Brothers, and Wolsey Ltd.

Amongst a broad range of topics, MRG 1 discussed the Bedaux system, fatigue, and rest pauses in the early 1930s. Whilst $C$. Walton, of Lever, expressed extreme suspicion of organized rest pauses, the consensus was that well-organized spells of work, punctuated with periodic rest and refreshment periods, preferably combined with some change of posture and movement, gave the best physiological effects, reduced industrial fatigue, and resulted in enhanced output at no adverse cost to the workers' health. ${ }^{90}$ This indicates that some of the crucial tenets of IHRB ideology were beginning to penetrate the minds of a number of enlightened industry leaders. Whether such practices were widespread on the shop floor in such firms is another matter. Regrettably, MRG 1 did not undertake a systematic survey of work spells and rest pauses amongst its member firms.

The British Science Guild (BSG) also played a part in disseminating the research work of the IHRB in the 1920s and 1930s. The BSG was founded by Sir Norman Lockyer in 1905 and composed a membership of around 930 individuals in 1920, mostly academics and enlightened industrialists. ${ }^{91}$ In the inter-war years, a number of IHRB and ex-HMWC staff had links with the Guild, including W. Fletcher, C. Sherrington, C. S. Myers, T. Barlow, and L. Hill. Its main function was "to convince

\footnotetext{
${ }^{86}$ Munro, op. cit., note 59 above, p. 12.

${ }^{87}$ Management Research Groups (MRGs) Archive, Business History Unit, London School of Economics, File No. W/P/38. See also S. P. Keeble, 'Management Research Groups', Business Archives, 47, November 1981.

${ }^{88}$ MRGs, First Annual Report, 1 January to 31 December 1927, p. 1.

${ }^{89}$ MRGs, Constitution, January 1933, p. 1.

90 MRG No. 1, Minutes of the Labour Section, 3 March 1932.

${ }^{91}$ British Science Guild, Journal, no. 10, January 1920, p. 2.
} 


\section{A. J. McIvor}

the nation of the necessity of applying methods of science to all branches of human endeavour, and thus to further the progress and increase the wealth of the Empire."92 It developed into a pressure group promoting public awareness about the connexions between science and industry, agitating for improved educational facilities and increased financial support-state and private-for scientific research and generally to improve the status of science and the utilization of scientific methods in the running of the country. ${ }^{93}$ This included the promotion of scientific methods of labour management and particularly the implementation of the research work of the Board and the NIIP. ${ }^{94}$ The Guild thus championed vocational selection and training, motion study, fatigue studies, rest pauses, experimentation with work spells, and improved machinery design. It also encouraged a drastic shake-up in British management to achieve the input of men of scientific background and training. The practical impact of the Guild's work, however, is difficult to assess, and in 1936 it was finally absorbed into the British Association for the Advancement of Science.95

A number of organizations and groups concerned specifically with industrial health and welfare also played a part in digesting and disseminating the results of the IHRB's research. Welfare and medical officers employed in firms provided an important link between research and practical application, as did the Factory Inspectorate. On a smaller scale, the Industrial Welfare Society (IWS) performed a similar role to the NIIP, in so far as they gave coverage to IHRB findings in their journal and based many of their "practical plans for welfare work" which went beyond statutory requirements on the work and findings of the Board in this field. ${ }^{96}$ The IWS was founded in 1918 by R. R. Hyde, one of B. S. Rowntree's staff at the Welfare Department of the Ministry of Munitions. Hyde was director of the Society throughout the inter-war period. ${ }^{97}$ Contacts between the Society and the Board were close and cordial, with contributions from the Board being published in the journal of the IWS, Industrial Welfare and Personnel Management. ${ }^{98}$ The Industrial Health Education Council and the New Health Society did much to expose the considerable losses of industrial efficiency caused by preventable occupational diseases, malnutrition, accidents, poor hygiene, and general personal health. ${ }^{99}$ This was where the borderline between scientific management and the "national efficiency" movements became obscured and fragmented into numerous, often ephemeral but good-intentioned organizations.

Finally, it might be noted that the spread of psychology and physiology teaching in colleges and universities played its part in accelerating the diffusion of the Board's findings. Indeed, as the Board's reports were deliberately designed as scientific

92 Ibid., no. 1, September 1915, p. 2.

93 Ibid., Second Annual Report, 15 January 1908, p. 5; Journal, no. 21, March 1926, p. 21.

94 Ibid., Journal, no. 17, February 1924, pp. 31-32; Journal, no. 18, June 1924, p. 27.

${ }^{95}$ The extensive archives of the British Science Guild, housed at the Bodleian Library, Oxford, deserve much more detailed analysis.

${ }_{96}$ IHRB, Annual Report, 30 June 1932, pp. 46-47.

97 For a brief discussion of the broader role of the Industrial Welfare Society see H. Jones, 'Employers' welfare schemes and industrial relations in inter-war Britain', Business History, 25: 1983, 67-68.

${ }_{98}$ Letter, IWS to IHRB, 20 October 1939; Letter, IHRB to IWS, 26 October 1939, MRC Archives, File No. $2080 / 21$.

99 The Industrial Health Educational Council, Confederation of British Industries, Predecessor Archive, Modern Records Centre, Warwick University, MSS 200/B/3/2/c692 part 3. 
research monographs open to academic scrutiny and criticism, this was probably the level at which the most extensive degree of comprehension of their findings took place (some might argue the only level?). Certainly, nearly all of the permanent investigating staff of the IHRB in the 1930s held academic posts: for example, E. Farmer was a reader in industrial psychology at Cambridge University; S. Wyatt was a lecturer in the department of psychology at Manchester University; T. Bedford was a lecturer in the department of industrial physiology at the London School of Hygiene and Tropical Medicine; and M. Culpin held the chair in industrial medical psychology at the University of London. ${ }^{100}$ This mode of diffusion was severely limited, however, by the very tenuous links that existed in the inter-war years between academe and industry.

In sum, the results of the IHRB's work were percolating through to industry from a number of sources, and some significant successes indicate at least a degree of penetration of the industrial psychology and fatigue studies ideology to the workplace in the 1930s. Clearly, many of the largest firms, especially those in the expanding, newer sector of the economy, which often enjoyed a protected market position, were aware of its work and had adopted some changes in labour management in line with its research. ${ }^{101}$ The formation of the NIIP and the continuation and development of its work in the 1920s and 1930s reflects industry's increased interest in industrial psychology and fatigue studies. Moreover, from the mid-1930s, a number of government departments were officially recognizing the science of vocational psychology as an aid to the recruitment and selection of adolescents for particular jobs and occupations, and the Army Council adopted psychological selection tests for recruits. ${ }^{102}$ The idea of music being piped into the workplace to relieve monotony was accepted by a number of employers, and the demand was such that the BBC produced the 'Music While You Work' programmes in the late 1930s. The consolidation of the 1918-19 reduction in working hours (to around 47-8 per week for the majority of British workers) over the 1920s and 1930s, and the Holidays with Pay legislation of 1938-9, also undoubtedly owed something to the Board's propaganda that excessive working hours were uneconomical as well as unhealthy. The 1937 Factory Act, moreover, incorporated the results of IHRB work into the value of short rest pauses, guidelines on weight-carrying, and the use of special spectacles for fine, close work. ${ }^{103}$ It also legalized the 48-hour working week as a maximum, reduced permissible overtime to six hours per week, made the provision of washing, cloakroom, and seating facilities compulsory in all factories, and included provisions empowering the Secretary of State to enforce regular medical inspection of workers where he had reason to believe that illness might be due to the nature of the work. ${ }^{104}$ This significantly extended the 1901 Act and the role of preventive medicine in industry, thus raising basic standards of health, safety, and welfare.

The point should clearly be made, however, that it was predominantly the expanding, relatively prosperous, modern sector of the economy, based largely in the

100 IHRB, Annual Report, 30 June 1935, pp. 8-9.

101 Ibid., 30 June 1933, p. 26; 30 June 1937, pp. 26-27; 30 June 1939, p. 22.

102 Ibid., 30 June 1935, p. 27.

103 IHRB, Annual Report, 30 June 1938, p. 59.

104 Factory Inspector's Reports, 1937, Cmd. 5802, pp. 5-7, 52, 73; 1938, Cd. 6081, pp. 87, 92. See also HMSO, A guide to the Factories Act, 1937. 


\section{A. J. McIvor}

Midlands, South and South-East of England-including electricity, electrical goods, motor-car manufacture, food-processing, aircraft, chemicals, plastics, artificial fibres-that registered the most positive response to new ideas relating to industrial health and efficiency. Working conditions varied considerably, therefore generalizations are difficult. Yet it was amongst these industries that industrial health was qualitatively improving in the inter-war period. ${ }^{105}$ The new factories embodied the latest innovations in design and construction and were generally much better illuminated (large windows and use of the sodium discharge lamp), heated, and ventilated, were safer (for example, in terms of access to fire escapes), and had the most up-to-date sanitary arrangements. ${ }^{106}$ As D. R. Wilson, the Chief Factory Inspector, noted in 1937 in discussing the advantages inherent in migration to the South for employment: "Another advantage gained by such transfers is that light and airy modern, single-storey factories, scientifically planned to economise labour, and situated in open and healthy surroundings, take the place of the old, many storeyed buildings with their restricted supply of fresh air and daylight. Work is consequently carried on under far more advantageous conditions both as regards the health of the workers and economy of labour and overhead charges."107 Moreover, some progressive employers also introduced regular medical inspection and welfare facilities, 1,800 welfare officers and around 1,500 nurses being employed full-time in industry in $1939 .{ }^{108}$ Motives for the introduction of such facilities were only partially altruistic. Medical care was considered by many to be a paying proposition, designed specifically to increase the overall efficiency, and hence profit margin, of the plant. ${ }^{109}$

The utilization of electricity as a power source in these new factories and its spread to some older plants, facilitated by the completion of the National Grid in 1933, considerably enhanced and improved healthy working conditions. One result was the implementation of much more efficient lighting systems - particularly noticeable in factories located in rural districts-utilizing sodium discharge and mercury vapour discharge lamps. ${ }^{110}$ The noise levels of older, mechanical transmission driving was also much reduced with electricity, and this facilitated the introduction of the wireless into factories in the later 1930s. ${ }^{111}$ Moreover, the use of electricity as a prime mover meant not only much more flexibility and efficiency in power transmission, but also the elimination of the chaos of drive belts, shafts, pulleys, and gears, which characterized the nineteenth-century steam-powered workshop and mill, and which were the cause of innumerable accidents, many fatal. ${ }^{112}$ Electric drive also enabled emergency stop-

${ }^{105}$ Branson and Heinemann, op. cit., note 63 above, p. 88.

106 Factory Inspector's Report, 1933, Cmd. 4657, pp. 13-14, 49.

107 Ibid., 1937, Cmd. 5802, p. 13.

${ }^{108}$ S. Pollard, The development of the British economy, 1914-1967, 2nd ed., London, Edward Arnold, 1969, p. 346; J. Stevenson, British Society 1914-45, Harmondsworth, Middx., Penguin, 1984, p. 191. The employment of factory doctors, however, was still negligible. Only thirty-five full-time and around twice as many part-time doctors were employed in industry in 1939.

${ }^{109}$ Factory Inspector's Report, 1939, Cmd. 6251, pp. 35-36.

110 Ibid., 1938, Cmd. 6081, p. 27.

111 Ibid., 1934, Cmd. 4931, pp. 26-27; 1938, Cmd. 6081, p. 96.

112 D. Landes, The unbound Prometheus: technological change and industrial development in Western Europe from 1750 to the present, Cambridge University Press, 1970, p. 288; Branson and Heinemann, op. cit., note 63 above, pp. 88-89; Factory Inspector's Report, 1935, Cmd. 5230, pp. 5, 24-25. 
motion devices to be installed much more cheaply and easily at every machine, or at least in every room. ${ }^{113}$ The importance of the latter in accident prevention was recognized when it was made compulsory from July 1938 under the 1937 Factories Act.

Whilst the newer, relatively prosperous industries provided, in general, a much healthier working environment, there were a number of negative aspects, arguably detrimental to the health and well-being of employees. Greater distances from home to work often added considerably to the working day. New technology and new materials replaced old health hazards with new ones. Skin cancers and dermatitis, for example, increased with the expansion in petrochemicals and plastics industries, whilst death and injury through electric shock partially, at least, compensated for the reduced accident rate registered on transmission machinery. ${ }^{114}$ This was partly a problem of ignorance of elementary technical principles of electricity, most of the worst accidents being to unskilled men. Glare produced by improper positioning and inadequate screening of new electric lighting systems was found to be a frequent source of worker fatigue and eye-strain by the Factory Inspectorate, who were also aware that new machinery created novel, unknown risks, especially through the potential for accidents in regard to unfenced moving parts. ${ }^{115}$

Moreover, it was in the newer, expanding sector of industry where the most far-reaching changes were taking place in the organization of work and re-design of the labour process. The tendency, as already noted, was towards work of a lighter and less skilled character, with tasks minutely sub-divided on the basis of crude flow production-epitomized by the Henry Ford-inspired conveyor-belt organization of motor-car manufacture. Such work produced, as the IHRB and the Factory Inspectorate testified, new problems of monotony at work linked with intangible and unquantifiable indications of mental stress, anxiety, and nervous tension. The comments of J. C. Bridge, Senior Medical Inspector of Factories, in 1931 are worth citing in some length:

\begin{abstract}
It is true that the pleasure of the craftsman is being crushed by the steady increase in mechanised processes, the result of which is seen in the tendency to rise of sickness rates for 'nervous disabilities' .... Repetition processes undoubtedly create a weariness not expressed in physical terms but in a desire by the worker for temporary relief from the enforced boredom of occupation in which the mind is left partially or entirely unoccupied. This fact must be recognised for the understanding of sickness records and absenteeism in the industrial population. Vastly more days are lost from vague, ill-defined, but no doubt very real, disability due to ennui than from all the recognised industrial diseases together. How this state of affairs is to be controlled is a pressing problem of industrial health at this time. More interest in processes that are themselves dull must be created. Selection of workers is in this problem only of limited value; there are more dull tasks than people suitable for them. Industrial management may solve the difficulty-piece for time rates, a system of promotion on efficiency, bonuses of holidays for unbroken time-keeping, rest pauses with a change of posture and attention, are but a few suggestions in a problem which is a growing one. The uninterested worker is an industrial invalid. Interest in work leads to industrial good health. ${ }^{116}$
\end{abstract}

113 Ibid., 1938, pp. 32-33.

114 Ibid., 1935, Cmd. 5230, pp. 54-55; 1938, Cmd. 6081, pp. 50-52.

115 Ibid., 1934, Cmd. 4931, p. 26; 1936, Cmd. 5514, p. 8.

116 Ibid., 1931, Cmd. 4098, p. 75. See also 1936, Cmd. 5514, pp. 42-43. An interesting account of the health problems created by a light engineering firm in Milan much influenced by scientific management methods is provided by P. Willson, 'The golden factory', in Weindling, op. cit., note 2 above, p. 252. 
Women in particular suffered from mental exhaustion at work, and causal factors might be highlighted. The first is external to the workplace and reminds us that it is impossible to analyse health at work in a vacuum, for factors outside the workplacehousing, nutrition, family life - crucially affected health, and even the Senior Medical Inspector of Factories accepted that on balance "it is outside the factory where most of the ill-health arises". ${ }^{117}$ The root cause of fatigue amongst working women lay in their dual role as worker/housewife and child-rearer. The second factor is the very character of women's work, their participation in the labour market being restricted largely to the least skilled, least responsible, and most degraded of occupations. ${ }^{118}$ Whilst accepting that many employers provided good working conditions for women and arguing, somewhat obtusely, that women were somehow intrinsically more adaptable to boring, repetitive work, Sibyl Horner, a Medical Inspector of Factories, went on to comment:

\begin{abstract}
There is, however, an adverse side to industrial life for women, and this is evident to any observer who has the opportunity of studying women at work. They age quickly, their apparent age is the elder sister to their baptismal certificates. Physical attraction is early attained and quickly lost. But so it is with every group of women workers - these facts are not confined to women factory workers. The reason is, I think, this: women's work often begins when it nominally ends. The house and dependents make their claims on the woman worker. Her work is never done. She has, with the possible exception of the unmarried girl, fewer recreations or relaxations than her contemporary male. ${ }^{119}$
\end{abstract}

It was in the older, depressed, staple sectors of the economy-including textiles, coal, iron and steel, and shipbuilding - that industrial health standards stagnated in the inter-war years and absorption of innovatory "scientific" ideas on the physiological and psychological conditions conducive to industrial efficiency and worker health was extremely limited. Significantly, most of the IHRB initiatives were directed at identifying and exposing health and fatigue problems in these industries and prescribing preventive measures. Moreover, the Factory Inspectorate singled out the staple industries as providing the least healthy working environment, the result partly of older factory architecture, design, space allocation, technology, habits, and attitudes. ${ }^{120} \mathrm{~L}$. Bryder and G. Burke have also recently suggested that in two declining sectors, slate-quarrying in N. Wales and metal-mining in Cornwall, standards of health at work deteriorated between 1900 and 1939. ${ }^{121}$ Workers' health in the "basic industries" was further undermined by two related factors; first, the mental strain and tension of recurrent short-time working, unemployment, and redundancy; second, by

${ }_{117}^{11}$ Factory Inspector's Report, 1934, Cmd. 4931, p. 51.

118 B. Drake, Women in trade unions (1920), reprinted London, Virago Press, 1984, part III, section 1, 'Womens' place in industry', pp. 189-197; M. Philips, 'Women in industry', Ruskin College Reorganisation of Industry Series, II, 1917, pp. 36-49; Cronin, op. cit., note 58 above, p. 67.

119 Factory Inspector's Report, 1933, Cmd. 4657, pp. 50-51.

${ }^{120}$ Ibid., p. 41.

${ }^{121} \mathrm{G}$. Burke, 'Disease, labour migration and technological change: the case of the Cornish miners', in Weindling, op. cit., note 2 above, pp. 78-88. L. Bryder, 'Tuberculosis, silicosis, and the slate industry in N. Wales, 1927-1939', ibid., pp. 108-126. In Cornwall, lack of proper sanitary provisions led to outbreaks of ankylostomiasis (a type of intestinal worm) in conjunction with the more frequent occurrence of lung disease. See Burke, op. cit., pp. 83-85. 
the intensified workload, "speeded-up" work pace, and increased direct discipline that generally characterized the shop floor in these years. This is impossible to quantify or assess precisely. Nevertheless, in this sense those in work as well as those unemployed in the so-called "Depressed Areas" suffered a deterioration in standards of health and welfare.

Improving health and welfare was an expensive proposition open only to those firms showing regular profits and to industry leaders enjoying a relatively protected and buoyant market position. Quite the opposite economic scenario confronted employers in the depressed staple sectors, most of whom lacked the financial resources to make voluntary improvements in working conditions. Such firms were wary, moreover, of increasing costs which might not be matched by their competitors, thus conferring a crucial disadvantage in a cut-throat market place. Consequently, the employment of factory welfare officers, nurses, dentists, and doctors was often considered an extravagance, and capital was frequently not available for electrification, lighting renewals, and technological improvement. Two examples help to illustrate this.

First, the Burnley Weavers' Association complained in 1935 that artificial lighting in the town's cotton-weaving sheds was so poor that it resulted in serious eyestrain and fatigue. The Factory Inspectorate confirmed this finding by an examination of illumination in eight sheds. ${ }^{122}$ Two years later, it was reported that there had been little improvement and that wool and cotton employers took almost no interest in efficient industrial lighting, despite its importance as a source of significant productivity losses. As the Chief Factory Inspector noted; "The subject is, however, difficult, and needs expert technical consideration of spacing, intensity and dispersion and few of the cotton manufacturing firms can at present afford the expert survey and the cost of a reorganised and re-arranged lighting system." 23 Consequently, poor lighting arrangements added to the discomfort of working in weaving-sheds artificially steamed to raise humidity and to prevent frequent breakages of heavily sized, inferior yarns and the risk of contracting byssinosis ("weaver's cough") from "shuttle kissing" (sucking the yarn through the shuttle). ${ }^{124}$

Second, the cotton spinning-mule was responsible for a skin cancer (epitheliomatous ulceration) which was described by 1933 as "now the most menacing of all the industrial diseases that are notifiable". ${ }^{125}$ This usually affected the scrotum, and was caused by the use of carcinogenic mineral oil as a lubricant on the spindles, which splashed on to the clothing of the mule-spinners and piecers. From 1923 to 1936, 918 cases were reported, 305 of which resulted in deaths, often ghastly and excruciatingly painful. ${ }^{126}$ The obvious preventive measure, periodical medical examination, was rejected by employers on the grounds of cost and custom, and little capital was available to make the switch to the alternative, less risky spinning technology, the ring frame. Long overdue, a simple anti-splash device (whereby the spindle was lubricated

122 Factory Inspector's Report, 1935, Cmd. 5230, pp. $20-21$.

123 Factory Inspector's Report, 1937, Cmd. 5802, p. 24. See also 1936, Cmd. 5514, p. 18.

124 A. Bullen, The Lancashire Weavers' Union, Manchester Free Press, 1984, p. 21.

125 Ibid., 1933, Cmd. 4657, pp. 9-10. See also H. A. Waldron, 'A brief history of scrotal cancer', Br. J. indus. Med., 1983, 40: 390-401.

${ }^{126}$ Factory Inspector's Report, 1936, Cmd. 5514, p. 48. 
by contact with an oil-soaked pad) was first utilized by a large spinning firm in $1938 .^{127}$ Significantly, however, neither the addition of this device, nor provision for regular medical supervision was incorporated in the 1937 Factories Act.

The IHRB were themselves bitterly disappointed, to the point of exasperation, at the very poor response of British management, the negligible diffusion of their findings, and the relatively insignificant practical application of their research into industrial health and efficiency on the shop floor in the 1930s. As the Board noted in 1934: "Neglect of physiological principles at work is not far to seek. It is plain to the eye, in every variety of occupation, that man is often put at a physical disadvantage in the use of the tools and machines of his trade." ${ }^{128}$ R. T. Medd, a prominent NIIP researcher, added weight to the Board's views when he noted in 1938 that the industrial world was making no active efforts to implement the Board's research work. ${ }^{129}$ Furthermore, the initial experience of the war, 1939-40, added fuel to this pessimistic indictment of British industry.

The Second World War provided a crucial test of whether the work of the industrial psychologists and the fatigue studies experts which emerged out of the 1914-18 war had been absorbed by British industry. The Board was clearly aware of the dangers and published in the early part of 1940 the first of its 'Emergency Reports', summarizing previous research findings in simple, non-technical fashion. ${ }^{130}$ The response was negative and a large section of industry stumbled into the same kind of mistakes that were made in 1914-15. After the disaster of Dunkirk in June 1940, the upsurge in patriotic fervour and the perception of the possibility of invasion resulted in excessively lengthening working hours as industry responded to the call for an acceleration in munitions manufacture and the replacement of equipment left on the French beaches. ${ }^{131}$ Ironically, this was encouraged by Ernest Bevin, Minister of Labour, an ex-member of the IHRB in the 1930s. This was a repeat of the scenario of 1915 and the "shell scandal"-with similar repercussions. Work was considerably speeded-up, working hours rose (commonly to 70-75 hours per week), holidays were cancelled, and Sunday working implemented. The initial rise in output could not be sustained, however, as the ill-effects of accumulating fatigue manifested itself in increased sickness rates, absenteeism, and a declining capacity to perform normal work tasks adequately. The analogy of a forced sprint during the early part of a marathon race was again referred to by the Board, the Factory Inspectorate, and the MRC, who lamented that the work of the Board since 1918 on the physiological and psychological conditions most conducive to optimum efficiency had been largely ignored: "It is regrettable that but little was known about this work either by many industry leaders or by the mass of workmen in the early stages of the war. Had this information been more widely appreciated it might have been possible to avoid the introduction of those excessively strenuous working conditions in the period immediately following the

127 Ibid., 1938, Cmd. 6081. p. 72.

128 IHRB, Annual Report, 30 June 1934, p. 24.

129 Munro, op. cit., note 59 above, discussion, p. 20.

130 IHRB Emergency Report No. 1, 'Industrial health in war', London, HMSO, March 1940.

131 Committee of the Privy Council for Medical Research, 'Medical research in war: report of the MRC for the years 1939-45', London, HMSO, December 1947, Cmd. 7335, p. 153; Factory Inspector's Reports, 1939, Cmd. 6251 , p. $19 ; 1940$, Cmd. 6316, pp. 3, 18-19. 
evacuation from Dunkirk which proved incompatible with a large sustained output from the factories and with a good standard of health among the workpeople."132

Therefore, whilst rationalizing labour management techniques were gaining ground in the inter-war years, especially amongst the newer firms in the expanding sector, evidence nonetheless suggests that a large proportion of British industry continued to lack any positive attitude towards experimentation, work measurement, and scientific analysis of the workplace. Why was this? How can the relative failure of the IHRB pre-1939 to push forward the parameters of industrial health and efficiency be explained? It will be argued that the interaction of three major factors are primarily responsible; marketing constraints, financial cost, and management receptivity.

In marked contrast to the Bedaux consultants, the IHRB failed to market its product well. The Board admitted in 1932 that the most difficult part of its work was the publicizing of its research results and ensuring their application in industry. ${ }^{133}$ The main vehicle for the dissemination of the Board's research was its Annual Reports and lengthy research monographs. These were solid, detailed pieces of scientific, empirical research, couched in technical language and medical jargon, designed specifically to withstand academic criticism at the very highest level. The Board justified this approach by claiming that its primary role was to press forward with fundamental research on the frontiers of scientific knowledge, present its findings, and not get involved in any wider propaganda work on its own behalf. ${ }^{134}$ The result, however, was that the work of the Board could rarely be easily digested by its main potential audience: employers, directors, works managers, trade union representatives, and workers themselves. Very few IHRB reports thus sold well enough to go into a second edition (i.e., over 1,000). The Board became increasingly aware of this gap in communication towards the end of the 1930s and appointed a Sub-Committee on Publicity to investigate. HMSO marketing was criticized as restrictive and its advertising as minimal, and reforms were implemented. ${ }^{135} \mathrm{~A}$ short synopsis of research was subsequently written in "popular language", distribution channels opened up with employers' associations, trade unions, and industrial research associations, and articles popularizing the Board's work forwarded to the press-including, on occasions, the Daily Mirror and the Daily Herald. It was not until 1943, however, that the Board initiated a new series of short pamphlets of a non-technical nature summarizing research results for the specific use of industry. Part of the problem in the inter-war years, therefore, was a communication gap. Large sections of industry were simply ignorant of the work of the IHRB.

Moreover, as we have already noted, market pressures reduced profit margins to such an extent that there was often little capital available to finance innovatory health and welfare schemes, especially amongst the most depression-hit industries and the smaller firms. The experience of the IHRB was that the depression made employers much more insular and narrowed their horizons as far as labour management was

\footnotetext{
132 Committee of the Privy Council for Medical Research, 1947, op. cit., note 131 above, p. 22.

133 IHRB, Annual Report, 30 June 1932, p. 41.

134 Ibid., 30 June 1938, pp. 59-60.

135 IHRB, Sub-Committee on Publicity, Minutes, 19 January 1939, MRC Archives, File No. 2080/2C.
} 


\section{A. J. McIvor}

concerned. ${ }^{136}$ The involvement of industry in the work of the Board registered a marked decline from 1921 as employers became preoccupied with economy, internal affairs, and with staying afloat in a much more intensely competitive market environment. The Management Research Group movement found the same tendency at work over the 1929-33 slump, when total membership fell from ninety firms to sixty-three. ${ }^{137}$ Employers looked for more tangible, short-term palliatives, such as slashing wages and increasing workloads. The "more looms" crisis in the cottonweaving trade is a case in point. ${ }^{138}$ Labour was relatively cheap, plentiful, and better disciplined during the recession and there was thus less incentive for employers to develop scientific methods of work which would conserve the energy expenditure, improve health, and increase the productivity of their workforce. Conditions of cut-throat competition during the 1920s and 1930s also tended to restrict the impetus of the employers who were interested in innovations in labour management techniques. As R. Langford of Renolds explained in a debate on the forty-hour working week: "A large number of workers were working long hours at low wages. In a highly competitive market, the progressive employers were hindered by the pricecutting of employers whose conditions of employment and rates of wages paid were deplorable." 139

Ignorance of the Board's work and severe financial constraints were significant factors retarding the penetration of its ideas. The two variables are interrelated in the sense that those who were aware of the ideology of the industrial health specialists would, one presumes, at least have absorbed one of its most basic tenets, that provision for industrial health pays in the long term through increased labour efficiency. A further, crucial factor was the lack of receptivity to new ideas on the part of British industry, both in terms of worker suspicion and, more significantly, managerial parochialism. The intensified class conflict and bitterness which characterized the inter-war period, particularly in the staple industries, was not the sort of environment that encouraged the formation of joint committees to discuss industrial health and efficiency, a fact recurrently lamented by the IHRB ${ }^{140}$ and highlighted by the Committee on Industry and Trade in 1929. ${ }^{141}$ Without such a formal "receiving" mechanism the work of the Board fell largely on deaf ears. Many workers felt, in the early days at least, that the IHRB was part of the broader rationalization movement, that efficiency was stressed to the detriment of welfare, and that the commitment to creating a healthy working environment was simply a smokescreen to obscure,

136 IFRB, Annual Report, 31 December 1924, pp. 26-27; 31 December 1926, pp. 18-20; IHRB, Annual Report, 31 June 1931, p. 77. See also I. H. Charley, The birth of industrial nursing, London (1954), 2nd ed., London, Baillière, 1978, p. 90.

${ }^{137}$ MRGs, Annual Reports, 1929 and 1933. An indication of the general lack of British interest in the scientific management movement in the 1920s is the fact that there were only eighteen registered delegates from Britain out of some 1,500 from thirty-five nations at the Fourth International Congress of Scientific Management, held at Paris in June 1929. See the MRGs, Annual Report, 1929, p. 25.

${ }^{138}$ See A. J. McIvor, 'Employers' associations and industrial relations in Lancashire, 1890-1939', PhD thesis, Manchester University, 1983, pp. 410-426.

${ }^{139}$ Discussion after a paper by H. M. Vernon, 'The probabilities and implications of the shorter working week', British Management Review, 1, no. 1, January-March 1936, p. 24.

140 IFRB, Annual Report, 31 December 1924, pp. 26-27; 31 December 1926, p. 20.

141 Final Report of the Committee on Industry and Trade, London, HMSO, March 1929, Cd. 3282, pp. 146-147. 
surreptitious forms of speed-up and intensified effort norms. ${ }^{142}$ Whilst the Board's image improved after the appointment of a trade union representative in 1924, and a better knowledge of its impartial orientation spread, still, a legacy of distrust continued into the early 1930s. This was not least due to the fear of unemployment, exacerbated, many felt, by the speed-up of work which characterized the 1920s and 1930s.

The initiative for changes in working methods and conditions lay clearly with management, and indeed, company executives laid great stress on retaining what they regarded as their prerogative to manage, without interference, as they thought fit. Witness, for example, the 1922 engineering lock-out on this issue. Mass unemployment precipitated a collapse in worker bargaining power and many employers responded not by rationalizing labour management and creating the physiological and psychological conditions conducive to optimum efficiency, but, alternatively with a fierce labour cost-cutting offensive in the traditional mode of labour management, incorporating wage reductions, de-manning, intensifying discipline and supervision, using cheaper forms of labour, speeding-up work, and using various methods of victimization to weed out militants and protesters. ${ }^{143}$ This was the predominant scenario in coal, cotton textiles, shipbuilding, iron and steel, and heavy engineering. Here, the spectre of high unemployment often induced significant improvements in productivity and, over the short-term, negated the need to rationalize scientifically methods of work. So, the response of a large section of industry to the more competitive market environment of the 1920s and 1930s was introversion, caution, and the utilization of a series of customary time-honoured tactics to slash labour costs. ${ }^{144}$ Scant regard was given to the provision of conditions conducive to workers' health and hence to industrial efficiency, and little attention was paid to those idealists who argued that this strategy was a poor long-term investment. ${ }^{145}$ As the response to the Bedaux system indicates, British employers were more concerned to develop systems to control labour, rather than to improve scientifically worker efficiency, via experimentation into work methods and energy expenditure.

This poor response of British industry to work measurement and scientific analysis of the labour process-and especially the work of the IHRB and the NIIP-was partly due to what might be termed the lack of a scientific and experimental habit of mind. ${ }^{146}$ This was in turn largely the product of the relatively poor status of science and management science in particular in the British education system, especially in comparison to the position in the USA and Germany. ${ }^{147}$ Employers and managers in Britain were thus often not in a position to understand or interpret the research findings of the Board, hence the cynical retort of the IHRB, that it was amongst this

\footnotetext{
142 Ibid., p. 147; IHRB, Annual Report, 30 December 1928, pp. 22-23; 30 June 1934, pp. 3-4.

143 For a discussion of employers' broader labour relations strategies and the role employers' associations played in the inter-war years in one industrial region, see McIvor, op. cit., note 138 above, chs. 8, 9, and 10 .

144 IFRB, Annual Report, 31 December 1926, p. 18; IHRB, Annual Report, 31 June 1931, pp. $75,77$.

145 R. M. Wilson, 'The care of human machinery', Oxford Lecture Conferences, 25 February 1922, p. 24.

146 Final Report of the Committee on Industry and Trade, March 1929, Cd. 3282, p. 216.

147 E. S. Byng, 'Administrative Management in Industry', British Management Review, II, no. 2, April-June 1937, p. 121. Some progress in management education had been made in the inter-war period, however, particularly at a number of higher educational institutions, including the London School of Economics, the Dundee School of Economics and Commerce, the Regent Street Polytechnic, and the Manchester, Birmingham, and Acton Technical Colleges.
} 


\section{A. J. McIvor}

group that vocational selection would be most useful. ${ }^{148} \mathrm{~F}$. W. Leggett, of the Ministry of Labour, went further by arguing bluntly that the vast majority of employers in firms with less than 100 workers were "too dumb or too apathetic" to digest the research findings of the IHRB or the NIIP. ${ }^{149}$

There was a serious communication gap betwien the Board and industry, which had its roots essentially in a clash between practical, hard-headed men of business and "ivory-tower" academics. The influential technical journal Engineering, for example, argued in 1923 that the work of the IHRB and the NIIP was largely theoretical and of little practical application as it stood. ${ }^{150}$ Research conducted by physiologists and psychologists in laboratories was criticized as being full of misinterpretations. Moreover, good labour management, continued Engineering, was not subject to scientific laws, but was the product of "prolonged experience", "intuition", and "necessary allowances ... put in by the eye". ${ }^{151}$ Judgement based on past experience was considered preferable to standard methods of work measurement. Consequently, the IHRB and the NIIP failed to attract the general confidence of the post-World War I engineering employers and indeed, were regarded with something approaching resentment as usurpers for their temerity in trying to instruct experienced businessmen and managers how best to manage their workforce. This lack of confidence in the work of the Board and a genuine scientific approach to work was reflected in the fact that requests for IHRB investigators and surveys in the 1920s and 1930s usually emanated from government departments, the Factory Inspectorate, the NIIP, and the Industrial Welfare Society, and only rarely from internal management or employers' associations. ${ }^{152}$ At the root of the problem, however, lay the ignorance of British management when it came to work experience and the labour process. Had managers been more aware of the psychological and physiological cost of manual work; had they critically observed methods and conditions of work in their factories, on the shop floor, they may well have modified their views towards fatigue, boredom and monotony, job specialisation, vocational selection, rest pauses, industrial disease, the work environment, etc. ${ }^{153}$

Of course, the weight of customary practice and traditional methods made habit-breaking particularly difficult. W. H. M. Jackson, of the Institute of Labour Management, lamented in 1938 that very few managements had developed a clearly defined personnel policy: "Lip service may be given, but in actual practice, with comparatively few exceptions, this amounts to little, for the old ideas have sway, and haphazard methods still prevail and are part of the inheritance of the past when there were ample sources of labour. With relatively few exceptions, personnel is relegated to

148 IHRB, Annual Report, 30 June 1936, p. 3.

${ }^{149}$ F. W. Leggett, 'Industrial relations', British Management Review, III, no. 3, July-September 1938, p. 69. Dr Leonard Lockhart noted in April 1928, regarding the employment of factory nurses: "Industry has not set out to make its appointments as attractive as it should; and this is very largely because its eyes are as yet fully opened neither to the value or scope of preventive medicine". Cited in Charley, (1978 ed.), op. cit., note 136 above, p. 102.

${ }_{150}$ Engineering, editorial, 'Industrial fatigue and its applications', 26 January 1923, p. 112.

151 Ibid.

152 IHRB, Annual Report, 30 June 1937, p. 28.

153 Group Report on 'Productive harmony', British Management Review, III, no. 3, July-September 1938, p. 109. 
a secondary place, and in the reconstruction years of the past decade, industrialists' thoughts, energies and resources have been mainly devoted to meet material requirements, rather than human needs and aspirations." 154 The creation of the physiological and psychological conditions conducive to optimum labour efficiency and health was a low priority for British management in comparison to the attention given to technical issues, materials, and sales policies. ${ }^{155}$

Moreover, management-particularly in the small and medium-sized firms-often retained many of the superstitions and fallacies of the past, including a belief in the linear relationship between hours of work and output (as was shown in the summer of 1940) and a refusal to accept Taylor's maxim (later absorbed within Fordism) that high labour costs could result in lower production costs per unit, if labour management techniques were rationalized. British employers in the staple industries appear to have been obsessed with the idea that slashing wages was the universal solution to all their problems, and this, together with the industrial relations conflicts and antagonisms it generated, obscured them from any rational attempt to address the fundamental problems of worker inefficiency and poor health. Industry, it was argued, was not a playground. Many employers were committed to the fallacy that workers should be seen to be grafting and sweating for their wages, and the idea floated by the HMWC and extended by the IHRB that work should be performed easily, with the minimum of physical and mental strain, was anathema to them. ${ }^{156}$ This goes back to the Taylorian concept that basically workers were innately lazy and had to be driven by financial incentives. Here lies the main objection of British management to the implementation of organized rest pauses to break up work spells, for this was, as C. Walton of Lever Brothers argued, simply encouraging indolence, for workers would continue to poach illicit breaks from production even when definite pauses were introduced. ${ }^{157}$ Moreover, this was the thin end of the wedge, which might lead to pauses being introduced in all departments with a commensurate increase in production costs. The argument that increases in productivity would result from reduced fatigue and healthier working conditions was still treated broadly with scepticism. Bearing this in mind and making allowances for the cluster of larger, newer, more progressive companies in the expanding sectors of the economy, L. Urwick's comment in 1937 that industry in Britain was still overwhelmingly dominated by "the nepotism, the politics and the traditionalism of the past" 158 seems a pertinent one. General standards of industrial health as a result made only marginal progress.

\section{Conclusions}

This essay has made an assessment of the origins, the work, the orientation, and the achievement of the Industrial Health Research Board, and through this medium, an

\footnotetext{
154 W. H. M. Jackson, 'A labour policy', ibid., p. 85.

155 Ibid., p. 92. And see R. Coppock, 'Management and labour relations of the future', ibid., IV, no. 4, October-December 1939, p. 33.

156 E. Farmer, 'Time and motion study', IFRB Report No. 14, 1921, p. 27.

157 MRG 1, Minutes of the Labour Section, discussion on fatigue and rest pauses, 3 March 1932, pp. 8-9.

158 L. Urwick, 'The scientific management movement', British Management Review, II, no. 2, April-June 1937, p. 17.
} 
attempt has been made to shed some insight into the general question of health and efficiency at work during the inter-war years. It has been shown how the Board emerged out of the war emergency, 1914-18, as a progression from the more limited work of the HMWC. It pioneered the scientific study of work in Britain and its main achievement was in vastly extending theoretical knowledge of the physiological and psychological principles governing the healthy and most efficient employment of workers in industry. Its research reports are an exhaustive data source on the way work was organized in Britain and the impact of occupation on workers' health. The Board identified and exposed problems of industrial health and advocated a whole range of preventive measures, including reduced working hours, rest pauses, redesign of the labour process, vocational selection and training, and the reorganization of the general work environment conducive to the highest standards of industrial health.

Its orientation and its motivations are revealing. Its ideology squarely bridged that of the American-inspired efficiency engineering movement and the endogenous welfarist school, epitomized by Cadbury and Rowntree. It advocated a more scientific approach to labour management via detailed investigation and experimentation in the workplace, using time and motion studies, amongst other techniques. This earned it, at least initially, the distrust of organized labour. Yet the Board distanced itself from American management techniques and stressed a much more personal approach, arguing repeatedly that workers were complex psychological and physiological organisms exhibiting great diversity in energy levels and capacity to work. The primary object of the Board's work studies was to improve standards of workers' health. Its motivations, however, were not entirely altruistic, paternalist, or humanitarian in the traditional welfarist sense. It continually emphasized that industrial medicine paid dividends in terms of enhanced worker productivity and thus industrial efficiency; crudely, that there was a direct correlation between standards of workers' fitness and health and profit margins in British industry.

The diffusion of the IHRB's findings and the penetration of its ideology was limited prior to World War II. It has been argued that the large employers in the expanding, modern sector of the economy were most receptive to innovatory labour management ideas emanating from the Board, and that it was in this sector that industrial health was qualitatively improving in the inter-war period. Moreover, the government took the initiative in the 1937 Factories Act to incorporate a number of the Board's findings and modestly to raise basic standards of health, safety, and welfare at work. This was a significant watershed. However, prior to $1937-8$, there is evidence of a growing dichotomy in health standards at work between the new industries and the older, depressed staple sector of the economy, where working conditions deteriorated and where absorption of scientific management ideas on the physiological and psychological conditions conducive to industrial efficiency and workers' health were negligible. ${ }^{159}$ Indeed, most of British industry registered a negative response to IHRB

\footnotetext{
${ }^{159} \mathrm{H}$. Jones has noted that "inequalities in standards of safety and conditions of health between firms and regions increased as the legal standards remained those laid down in the 1901 Factory and Workshop Act". See H. Jones, 'An inspector calls: health and safety at work in inter-war Britain', in Weindling, op. cit., note 2 above, p. 223.
} 
ideology and remained committed to traditional labour management methods. This was the result partly of poor marketing methods by the Board and partly of financial constraints in a period of recession militating against change. Primarily, however, the lack of progress has its roots in the poor receptivity of British industry to scientific concepts and particularly the narrow parochialism and traditional fallacies of many, though not all, employers and managers. This is a salutary reminder that generalizations based on the best practice of the thin strand of "progressive" large firms in Britain can produce distortions of reality. In fact, in the older, staple sectors of the economy the penetration of "scientific management" was negligible, industrial health at best stagnated, and for a large number of workers qualitatively deteriorated prior to 1937-8. In the larger firms, in the newer relatively prosperous sectors, there were advances, yet the potential for improving workers' health, welfare, and efficiency, as indicated by the pioneering research work of the HMWC and the IHRB, was rarely realized in inter-war workshop practice. 